\title{
STOLPER-SAMUELSON REVISITED: TRADE AND DISTRIBUTION WITH OLIGOPOLISTIC PROFITS
}

\author{
Robert A. Blecker* \\ American University, Washington, DC
}

(October 2011; revised February 2012)

\begin{abstract}
This paper investigates the distributional impact of international trade when goods markets are oligopolistic and firms partially pass-through changes in tariffs into prices and factor costs for differentiated products. Trade liberalization raises mark-ups and profit shares in the export industry and lowers them in the import-competing industry, while Stolper-Samuelson effects on real prices of primary factors are attenuated or possibly reversed. An extended model shows how "offshoring" (trade in intermediate goods) can potentially increase mark-ups for oligopolistic producers of final goods. The analysis illuminates why business interests generally support trade liberalization policies today, regardless of their countries' factor abundance.
\end{abstract}

Professor and Chair, Department of Economics, American University, Washington, DC 20016 USA, E-mail: blecker@american.edu.

*The author would like to thank Bruce Elmslie, Bob Feinberg, Alan Isaac, Mehrene Larudee, Will Milberg, Arlsan Razmi, Gil Skillman, Lance Taylor, and two anonymous referees, along with participants in the Annual Political Economy Workshop (Queen Mary University of London, 2007), the Bernard Schwartz Center for Economic Policy Analysis (The New School, 2008), and the Eastern Economics Association meetings (New York, 2009), for helpful comments and suggestions on earlier drafts. The usual caveats apply.

JEL Classifications: F11, F12, D33, D43, E12 


\section{INTRODUCTION}

It is now more than three decades since the "old" theories of international trade based on the assumption of perfect competition began to be supplemented by "new" theories that analyzed trade under conditions of imperfect competition (Krugman, 1979; Grossman, 1990). Yet, with some exceptions, the analysis of the distributional impact of trade has continued to be based largely on models that assume perfect competition in goods markets as well as factor markets. In particular, the theorem of Stolper and Samuelson (1941) remains the core modeling framework for analyzing the distributional effects of trade. In the original version of this theorem, free trade raises the real price of a country's abundant factor of production and lowers the real price of its scarce factor. Many alternative analyses, such as Feenstra and Hanson’s (1996) model of trade and distribution with intermediate inputs produced by varying proportions of skilled and unskilled labor, still assume perfect competition in both goods and factor markets.

Nevertheless, the literature on trade in oligopolistic markets has reached some fairly robust conclusions that have strong implications for how changes in trade policy (e.g., tariff reductions) affect the profits of oligopolistic firms. A large literature, surveyed in more detail in the next section, has found that oligopolistic firms may only partially “pass-through" changes in tariffs or exchange rates into prices of tradable goods; when this occurs, firms also adjust profit mark-ups (or price-cost margins) as part of a “pricing-to-market” strategy. Yet, to date there have been remarkably few efforts to re-integrate the lessons from the literature on partial pass-through and flexible mark-ups with the core models of international trade and income distribution. ${ }^{1}$

\footnotetext{
${ }^{1}$ One notable exception is Helpman and Krugman (1985), who derived the conditions for factor price equalization to hold in a three-good model where one sector is oligopolistic, and also demonstrated that Stolper-Samuelson predictions about winners and losers from trade can be reversed in the presence of scale economies. However, they did not consider changes in oligopolistic mark-ups as an explanation of the effects of trade on profits as we do here.
} 
In the past two decades, most of the empirical literature on trade and income distribution has focused on the effects of trade on the relative wages of so-called "skilled" and "unskilled" labor. In many of these studies, the overall distributional effects of trade, including the impact on capital, are either not emphasized or ignored altogether. ${ }^{2}$ The lack of attention to the impact of trade on the distribution of income between capital and labor is even more striking when one considers the political economy of contemporary trade policy, in which large corporate interests are usually the chief promoters of trade liberalization and economic integration, regardless of the abundance or scarcity of capital in a country. For example, Pastor (2011, p. 97) observes that “Businesses — multinational corporations (MNCs), banks, and small and medium-sized firms— have been the main agents for economic integration” in all three North American countries, yet only one of them (the US) can be considered capital-abundant while (on a regional basis) Mexico is relatively labor-abundant and Canada is natural resource-abundant. Recently, some attention has been focused on whether globalization or offshoring is leading to a rise in the profit share of national income (e.g., Onaran, 2009; Milberg and Winkler, 2010), but so far this work is mainly empirical and the results have not been re-integrated into trade theory.

This paper contributes to that theoretical reintegration by drawing upon theories of oligopolistic mark-up pricing to model the profits of business firms, while continuing to treat the returns to primary factors of production in the traditional Stolper-Samuelson (S-S) manner. In models that assume perfect competition, the returns to capital are identified with the scarcity rents on fixed (and fully utilized) supplies of capital equipment, while firms are assumed to receive zero economic profits. However, following the approach pioneered by Kalecki (1954 [1968]), in the presence of oligopoly with excess capacity, firms receive profits based on the

\footnotetext{
${ }^{2}$ Exceptions include Thompson (1997), Leamer (1998), and Feenstra and Hanson (1996), who included capital in three-factor models (along with skilled and unskilled labor). However, all of these assumed perfectly competitive goods markets; none incorporated partial pass-through of tariff changes or adjustments in mark-ups.
} 
rents due to their market power rather than the scarcity of their capital. In this context, if a change in trade policy alters the economic profits of oligopolistic firms, its impact on the returns to the primary factors of production (such as labor or natural resources) will be different from the predictions of standard S-S models that assume zero profits.

The basic S-S insight that trade affects the prices of primary factors of production by changing the prices of goods that utilize these factors in different proportions remains a key foundation for any analysis of the distributional impact of trade, and should not be discarded. Nevertheless, the S-S theorem has to be modified when the assumption of perfect competition in product markets is replaced by oligopolistic competition with partial pass-through of tariff changes. We will show that S-S "magnification effects" on factor prices are attenuated by adjustments of profit mark-ups in industries with partial pass-through of tariff changes, and therefore some of the standard predictions about which factors experience absolute gains or losses need to be modified. ${ }^{3}$ We also obtain new results for the effects of trade on the profits of firms, which more resemble the predictions of a specific factors model applied to capital that is immobile in each sector (Jones, 1971; Neary, 1978), rather than a Heckscher-Ohlin (H-O) model with mobile factors. Finally, we will briefly suggest an extension of our modeling framework to address the distributional impact of the offshoring of intermediate inputs.

The rest of this paper is organized as follows. Section 2 reviews the relevant literature and discusses the conceptual framework. Section 3 presents a modified H-O model of trade with oligopolistic profits and mark-up pricing. Section 4 applies the model to the distributional effects of changes in foreign prices and tariff rates. Section 5 extends the model to offshoring. Section 6 concludes by discussing the implications of the model for the political economy of trade policy,

\footnotetext{
${ }^{3}$ This result was partly anticipated by Melvin and Warne (1973), who briefly noted that S-S does not hold in the case of pure monopoly. However, they did not analyze partial pass-through behavior in oligopolistic industries.
} 
the limitations of the present analysis, and directions for future research.

\section{LITERATURE SURVEY AND CONCEPTUAL FRAMEWORK}

A large literature on theoretical models of international trade with oligopolistic markets arose in the 1980s. Some of the most prominent branches of this literature focused on the economic logic of reciprocal dumping (Brander and Krugman, 1983) and the potential for net welfare gains from “strategic trade policies” (Brander and Spencer, 1984a). Another branch of this literature (Brander and Spencer, 1984b; Feenstra, 1989) analyzed the partial pass-through of changes in either tariffs or exchange rates into prices of traded goods, a phenomenon which occurs when goods prices adjust by less than 100 percent of the tariff or exchange rate change in the destination country's currency. Typical results in this literature show that, for example, if a home country increases its tariff (or if the home currency depreciates), a profit-maximizing foreign oligopolist will reduce the own-currency price of its exports, thereby implying partial passthrough of the tariff (or exchange rate) change into the price of home country imports. Similarly, a tariff reduction (or currency appreciation) could induce domestic importing-competing firms to reduce mark-ups and prices in order to maintain market share in the face of falling import prices.

Brander and Spencer (1984b) demonstrated these types of results assuming Cournot oligopoly, while Feenstra (1989) found qualitatively similar results assuming Bertrand oligopoly. Thus, contrary to what Eaton and Grossman (1986) showed for the gains from strategic trade policies, the existence of partial pass-through behavior is not sensitive to these alternative assumptions about market structure. Arestis and Milberg (1993-94) showed that partial passthrough of exchange rate changes also results in Kalecki’s (1954 [1968]) model of mark-up 
pricing and Eichner’s (1976) theory of oligopolistic price leadership. Heintz (2006) models how oligopolistic firms can capture some of the gains from lower prices of imported manufactured goods, thereby only partially passing through the welfare gains to consumers.

Much of the early empirical literature testing these models was motivated by the limited responses of traded goods prices to the large exchange rate swings of the 1980s. Woo (1984), Mann (1986), and Dornbusch (1987) analyzed why US import prices did not change by the full amounts that would have been expected from the sharp appreciation and subsequent depreciation of the dollar in the 1980s. Ohno (1989), Marston (1990), and Parsley (1993) found empirical evidence for partial pass-through of yen appreciation into Japanese export prices. Feinberg (1986, 1989) estimated the pass-through of changes in exchange rates and import prices into domestic prices, which he found was more likely to be partial (as one would expect) in industries that were more concentrated and produced more differentiated products.

Most of these empirical findings have pertained to exchange rate pass-through (see Goldberg and Knetter, 1996, for a survey). However, Feenstra (1989) demonstrated that changes in tariffs and exchange rates have symmetrical effects on import prices in a theoretical model of an oligopolistic foreign export industry, and confirmed this symmetry empirically for US imports of motor vehicles from Japan. Later, Castañeda Sabido and Mulato (2006) found that tariff reductions squeezed profit margins in Mexican industries after Mexico liberalized its trade in the late 1980s. Mallick and Marques (2008) compared exchange rate and tariff pass-through for India, and found that exchange rate changes are more commonly (and more fully) passed through into import prices than tariff changes, while "firms exporting to India more frequently adopt strategies to maintain their market share against tariffs than against exchange rate changes” (p. 765). Nicita (2009) incorporated empirical estimates of partial tariff pass-through into a broader 
analysis of the impact of trade liberalization on household welfare and income distribution in Mexico.

Although the focus in most of this literature has been on the degree of pass-through into prices, the same models also imply that profit mark-ups (or price-cost margins) are likely to vary in systematic and predictable ways in response to either tariff or exchange rate changes in industries that exhibit partial pass-through behavior. For example, if either foreign countries raise their tariffs or the home currency appreciates, we would expect domestic exporting firms who “price to market” to reduce their own-currency export prices relative to their own-currency unit costs, thereby lowering their mark-ups. Similarly, if either the home country increases a tariff or the home currency depreciates, domestic import-competing firms would be expected to increase their prices relative to their costs (both measured in home currency), thereby raising their markups. Thus, the partial pass-through literature implies simple and intuitive "rules of thumb” for how profit mark-ups are likely to adjust in response to changes in tariffs or exchange rates. ${ }^{4}$ While these responses of prices and mark-ups are well understood, to the best of our knowledge they have not previously been incorporated into a S-S type of analysis of the impact of trade liberalization on income distribution.

In the approach proposed here, firms will be assumed to receive profits deriving from their oligopolistic rents, while the primary factors of production (various types of labor or natural resources) will be assumed to earn scarcity rents in the conventional fashion for comparability with traditional S-S models. ${ }^{5}$ The idea that mark-up pricing by oligopolistic firms can be used as

\footnotetext{
${ }^{4}$ Given that the previous literature is replete with models of how profit-maximizing firms make these decisions, we prefer to summarize the results of those models as rules of thumb rather than to replicate the models here.

${ }^{5}$ A series of articles, collected in Steedman (1979), showed that the core H-O theorems do not apply to capital when it consists of heterogeneous goods valued at prices that include positive profits; see Ethier (1979) and Smith (1979) for neoclassical rejoinders. However, Steedman and Metcalfe (1979) and Steedman (2005) have shown that the core $\mathrm{H}-\mathrm{O}$ theorems (including S-S) continue to hold when applied to primary, non-produced factors (such as labor and
} 
the basis for determining the profit share of national income was originally developed by Kalecki (1954 [1968]). ${ }^{6}$ We assume that oligopolistic firms typically operate with excess capacity, for a combination of well understood reasons: to maintain barriers to the entry of new firms; to anticipate future increases in demand; and because of indivisibilities in plant and equipment. Assuming excess capacity in a static framework, we can ignore the standard scarcity rents to capital, and treat all profits as deriving from oligopolistic mark-ups. However, from a formal viewpoint, nothing in the model developed below depends on this assumption; we could alternatively include capital as one of the primary factors of productions and assume that it is fully employed, in which case its owners would receive scarcity rents for the services of their capital in addition to any economic rents they derive from ownership of oligopolistic firms.

Turning to empirical studies of S-S effects, as noted in the introduction this theorem has often been applied to the effects of trade on wage inequality between more and less skilled workers, rather than the overall distribution of income between capital and labor generally. Empirical evidence for S-S effects in explaining the skilled-unskilled wage gap in the US economy is, however, mixed (see Lawrence and Slaughter, 1993; Thompson, 1997; Sachs and Shatz, 1998; Leamer, 1998; Krugman, 2008). Berman, Bound, and Griliches (1994) and Bernard and Jensen (1997) found that most of the changes in the US skilled wage premium had occurred within industries, rather than between them, contrary to what one would expect from S-S. This finding was initially interpreted as implying that skill-biased technological change, rather than trade, was the main "culprit" in explaining the rising skilled wage premium. However, several economists have demonstrated that trade can affect within-industry wage differentials, for

\footnotetext{
land) in the presence of heterogeneous intermediate goods, under certain conditions.

${ }^{6}$ Mark-up pricing as a device for determining the profit share was introduced into models of North-South trade by Taylor (1983) and Dutt (1988). However, these models assumed fixed mark-ups, and did not incorporate flexible mark-ups into a trade-theoretic analysis of factor-price determination as we do here.
} 
example as a result of the offshoring of inputs (Feenstra and Hanson, 1996) or heterogeneity of firms (Egger and Kreickemeier, 2009)—see Harrison, et al. (2011) for a survey.

Although these studies have made advances in understanding how trade affects the skilled wage premium, this literature has largely sidestepped the issue of how trade affects the overall distribution of income between capital and labor. A few recent studies have investigated how trade (or globalization more broadly) has affected relative shares of value added. Onaran (2009) finds that a measure of openness (export intensity) is negatively related to the wage share in the manufacturing sectors of Mexico and Turkey, but not South Korea. Milberg and Winkler (2010) find that measures of the offshoring of materials and services inputs have positive effects on profit shares using panel data for US industries. These studies are largely empirical and generally rely on existing theoretical models to motivate their econometric analysis.

Before proceeding to our own model, one caveat is in order. The literature on labor rents (e.g., Katz and Summers, 1989; Blanchflower et al., 1996) implies that a portion of the oligopolistic profits in concentrated industries may be captured by workers if they have strong bargaining power, for example as a result of union organizing or efficiency wages. In this vein, Bivens (2006) finds that labor’s bargaining strength declined in the US after the early 1980s because globalization improved what he calls the "fallback position" of capital. Rent-sharing by labor is not included in the model in the present paper, but could be incorporated in future extensions of this work. In order to sharpen the contrast between our results and the conventional S-S theorem, factor markets will be treated as perfectly competitive in what follows. 


\section{A MODIFIED HECKSCHER-OHLIN MODEL WITH MARK-UP PRICING}

We use a 2-good, 2-factor H-O model applied to a single, small country for simplicity; extensions to models with multiple countries or factors are left for future research. The two goods, 1 and 2, are produced using two primary factors of production, i.e., non-produced inputs. One of these factors will be called $L$ for labor, which may be interpreted as less-skilled labor or production workers. The other factor will be designated as $N$, which—depending on the desired application of the analysis—can be interpreted as either land (natural resources), skilled labor (human capital), or possibly physical capital. Hereafter, whenever we refer to "factor prices" we mean only the returns to $L$ and $N$, while oligopolistic profits are treated separately. Both factors $L$ and $N$ are freely mobile between industries but completely immobile between countries. We do not consider intermediate inputs in this section; they will be introduced later.

Using the dual cost functions that have become the standard workhorses of international trade models (Feenstra, 2004), but assuming oligopolistic firms with positive economic profits, the prices of the two goods can be expressed as follows: ${ }^{7}$

$$
\begin{aligned}
& p_{1}=\left(1+\phi_{1}\right)\left[w a_{L 1}+q a_{N 1}\right]=\left(1+\phi_{1}\right) c_{1}(w, q) \\
& p_{2}=\left(1+\phi_{2}\right)\left[w a_{L 2}+q a_{N 2}\right]=\left(1+\phi_{2}\right) c_{2}(w, q)
\end{aligned}
$$

where $a_{i j}$ is the quantity of input $i$ required per unit of output $j, w$ and $q$ are the prices of the factors $L$ and $N$, respectively, ${ }^{8} c_{j}(w, q)$ is the unit factor cost function for each good $j$, and $\phi_{j} \geq 0$ is the mark-up rate on good $j$. Since there are no intermediate goods, the share of profits (in the

\footnotetext{
${ }^{7}$ This specification could be justified by assuming that domestic output of each good is produced by a representative firm, which would be a pure monopolist in a closed economy, but which has to compete with foreign products in an oligopolistic world market as long as tariffs are not prohibitive. Alternatively, one could assume that each domestic industry consists of a small number of firms with identical cost functions, product varieties, and pricing behavior.

${ }^{8}$ Thus, $w$ is the wage rate for ordinary or less-skilled labor, while $q$ is either the rental rate on land (natural resources), the salary of skilled labor (human capital), or the rental rate on physical capital (plant and equipment).
} 
sense of oligopolistic rents) in value added equals the price-cost margin: $\pi_{j}=\left(p_{j}-c_{j}\right) / p_{j}=$ $\phi_{j} /\left(1+\phi_{j}\right)$, which is monotonically increasing in the mark-up rate $\phi_{j}$ in each sector $j=1,2$.

The input-output coefficients $a_{i j}$ can either be taken as fixed, or else treated as optimal coefficients derived by cost minimization from neoclassical production functions of the form:

$$
y_{j}=f_{j}\left(L_{j}, N_{j}\right), \quad j=1,2
$$

where $f_{j}(\cdot)$ is assumed to have all the usual "well-behaved" properties (constant returns to scale [CRS], diminishing marginal productivity, and satisfaction of all second-order conditions). ${ }^{9}$ In the latter case, the unit factor cost functions $c_{j}(w, q)$ are the optimal, minimized unit cost functions that are dual to the production functions (3). To enhance comparability with standard trade models, we will assume that the input-output coefficients $a_{i j}$ are flexible and are derived (via cost minimization) from production functions of the form (3), but all the qualitative results of this paper would still hold if there were fixed coefficients. ${ }^{10}$

To formalize the assumption of excess capacity, we can think of (3) as being embedded in a broader production function of the form,

$$
y_{j}=\min \left[f_{j}\left(L_{j}, N_{j}\right), \frac{K_{j}}{b_{j}}\right]
$$

where $K_{j}$ is physical capital and $b_{j}$ is a fixed coefficient for the ratio of capital to full-capacity output in each sector $j$. If we further assume that the binding constraint is always the employment of the primary factors $L$ and $N$, i.e., $f_{j}\left(L_{j}, N_{j}\right)<K_{j} / b_{j}(j=1,2)$, then the capital constraint is never binding, output is normally below the capacity level defined by the capital stock, and—if also

\footnotetext{
${ }^{9}$ When the $a_{i j}$ are derived by cost-minimization, they are functions of the factor prices, $a_{i j}=a_{i j}(w, q)$, but we suppress the factor prices here to avoid notational clutter.

${ }^{10}$ Although it is not otherwise implied by standard definitions of "well-behaved" production functions, we also assume that there are no factor-intensity reversals (FIRs), which requires that the elasticities of factor substitution for the two goods must not be too different. Assuming fixed coefficients is sufficient, but not necessary, to rule out FIRs. Assuming no FIRs is not strictly necessary for our results, but avoids introducing multiple equilibria.
} 
firms are static cost minimizers—-then capital would have a zero scarcity rent or "shadow price." ${ }^{\prime 1}$ However, nothing in the formal analysis below requires us to use ( $\left(3^{\prime}\right)$ under these assumptions; it is sufficient to use (3) and we could possibly define $N$ as physical capital (with a positive scarcity rent of $q$ ) if we so choose.

Assuming that the domestic industry consists of one or more oligopolistic firms with significant barriers to entry, there is no presumption that positive profits are competed away by new entrants or that profit rates are equalized across industries. Also, we do not assume identical technology (production functions) or identical homothetic preferences across countries. In fact, no assumption about preferences or technology (other than CRS in production) is required for the present analysis. ${ }^{12}$ We assume that, although finished goods markets are oligopolistic, factor markets are perfectly competitive, and hence factor prices are flexible and there is full employment of $L$ and $N$.

[Figure 1 about here]

Figure 1 represents a possible equilibrium for goods prices and factor prices in the model described by equations (1) and (2), assuming both goods are produced (i.e., incomplete specialization). How a specific equilibrium configuration of this type is determined in an open economy will be discussed in the next section; here we simply wish to illustrate how positive mark-ups $\phi_{j}>0$ drive a wedge between goods prices $p_{j}$ and unit factor costs $c_{j}$. The solid curves

\footnotetext{
${ }^{11}$ The author is not aware of any previous literature that explicitly uses the specification in equation $\left(3^{\prime}\right)$. However, this seems to be a mathematically convenient way to express the implicit assumption in many models with excess capacity that the capital constraint is not binding, while still allowing for possible substitution between other factors. Matters would grow more complicated in a dynamic setting in which firms also make investment decisions, but that would be beyond the scope of the present, static analysis in which the capital stock is taken as given.

${ }^{12}$ The original S-S theorem ("strong version”) assumed identical homothetic tastes and identical technologies across countries in proving that the abundant factor necessarily gains from free trade and the scarce factor necessarily loses. However, the more general S-S theorem ("weak version"), which states only that the factor used intensively in the good which goes up (down) in relative price gains (loses), requires only CRS and incomplete specialization but not identical technology or identical homothetic preferences. See Chacholiades (1978) and Feenstra (2004).
} 
labeled $c_{1}$ and $c_{2}$ represent the unit factor cost functions, $c_{j}(w, q)(j=1,2)$. These curves are drawn as convex to the origin on the assumption of positive and finite elasticities of substitution in the production functions (3); with fixed coefficients, these curves would be linear. The $c_{1}$ curve is drawn as steeper than $c_{2}$ assuming, without loss of generality, that good 1 is $L$-intensive, i.e., $\left(a_{L 1} / a_{N 1}\right)>\left(a_{L 2} / a_{N 2}\right) .{ }^{13}$ The equilibrium factor prices are $\left(w^{0}, q^{0}\right)$.

Under the standard assumption of perfect competition, goods prices $\left(p_{1}, p_{2}\right)$ would equal unit factor costs $\left(c_{1}, c_{2}\right)$, and the curves representing the latter could be called "zero profit conditions.” However, with positive mark-ups ( $\phi_{j}>0$ )—which for expository purposes we take as exogenously given here (adjustments in mark-ups are modeled in the next section)—prices are represented by the higher dashed curves $p_{1}$ and $p_{2}$. In the latter situation, factor market equilibrium occurs where $c_{1}$ and $c_{2}$ intersect, while the intersection of $p_{1}$ and $p_{2}$ has no particular significance. With positive mark-ups $\phi_{j}>0$, factor payments (total costs) are lower than the firms' total revenues, and the difference (i.e., the gap between the price and cost curves in Figure 1) is accounted for by firms' oligopolistic profits.

\section{EFFECTS OF TRADE ON INCOME DISTRIBUTION}

Next, we proceed to model how the distribution of income — both between the two primary factors $L$ and $N$ and between those factors and the profits of the firms that employ them—is affected by international trade. We assume that the domestic firms in each industry, 1 and 2, produce a final good that is an imperfect substitute for its foreign counterpart. The prices of the foreign varieties are $p_{1}^{*}$ and $p_{2}^{*}$, which are taken as exogenously given on the small country

\footnotetext{
${ }^{13}$ The slopes of the $c_{1}$ and $c_{2}$ curves are equal to $-\left(a_{L 1} / a_{N 1}\right)$ and $-\left(a_{L 2} / a_{N 2}\right)$, respectively.
} 
assumption. Thus, $p_{1}$ and $p_{2}$ are the prices of domestically produced varieties of the same goods, expressed in a common currency for convenience. Since home and foreign products are imperfect substitutes, we assume that there is two-way trade in both goods, and home and foreign varieties of each good do not generally sell for the same prices.

Suppose, without loss of generality, that the home country is a net exporter of good 1 and net importer of good 2. We assume also that the home country imposes a tariff on imports of good 2 but not on imports of good 1, i.e., there is no protection in the sector in which the country is a net exporter, and similarly the foreign country imposes a tariff on good 1 but not good 2 . Then, also assuming no transportation costs for simplicity, the price of home exports of good 1 in the foreign market is $p_{1}\left(1+t_{1}^{*}\right)$, where $t_{1}^{*} \geq 0$ is the foreign ad valorem tariff rate, and the price of imports of good 2 in the home market is $p_{2}^{*}\left(1+t_{2}\right)$, where $t_{2} \geq 0$ is the home tariff rate.

For mathematical convenience, we postulate the following reduced-form or rule-ofthumb relationships between home and foreign prices for each good:

$$
\begin{aligned}
& p_{1}=B_{1}\left(\frac{p_{1}^{*}}{T_{1}^{*}}\right)^{1-\beta_{1}} \\
& p_{2}=B_{2}\left(p_{2}^{*} T_{2}\right)^{1-\beta_{2}}
\end{aligned}
$$

where $B_{j}>0,0 \leq \beta_{j}<1(j=1,2)$, and, for notational convenience, we use "tariff factors" equal to one plus the tariff rates, $T_{1}{ }^{*}=1+t_{1}{ }^{*} \geq 1$ for home exports and $T_{2}=1+t_{2} \geq 1$ for home imports. In (4) and (5), the $B_{j}$ terms are constants that represent the qualitative characteristics that affect whether the home or foreign variety of each good, $j=1,2$, commands a higher price, while the exponents $1-\beta_{j}$ represent the degree of pass-through of the tariffs (or foreign prices) into home prices, which depends on the degree of substitutability of the home and foreign varieties of each good in consumption and the oligopolistic firms' strategic behavior (which are not modeled 
here explicitly, but rather incorporated into the $\beta_{j}$ parameters). Thus, $1-\beta_{j}$ is the elasticity of the price of the home variety with respect to a change in the tariff-adjusted price of the foreign variety. ${ }^{14}$ Perfect substitutes would imply $B_{j}=1$ and $\beta_{j}=0$, in which case there would be full pass-through; as the goods become less substitutable, $\beta_{j}$ rises above $0,1-\beta_{j}$ falls below 1 , and the pass-through into prices of domestic varieties becomes more and more partial.

Equations (4) and (5) pin down the domestic prices in relation to the (given) prices of foreign varieties; we need two additional equations to determine the mark-up rates and thereby pin down the unit factor costs in (1) and (2). ${ }^{15}$ For the mark-up on the export good, we assume

$$
\left(1+\phi_{1}\right)=\Phi_{1}\left(p_{1}^{*} / T_{1}^{*} c_{1}\right)^{\alpha_{1}}, \quad \Phi_{1} \geq 1,0 \leq \alpha_{1}<1
$$

where $\Phi_{1}$ is a constant reflecting other (exogenous) determinants of the home firms' mark-up rate, and $\alpha_{1}$ is the elasticity of the mark-up factor $\left(1+\phi_{1}\right)$ with respect to the ratio $p_{1}^{*} / T_{1}^{*} c_{1}$, which reflects home cost competitiveness (including the effect of the foreign tariff). ${ }^{16}$ Thus, when home exportables become more competitive with foreign products (because of a rise in the foreign price or a reduction in the foreign tariff), home firms in the export sector raise their mark-ups.

\footnotetext{
${ }^{14}$ Thus, equation (4) implies that a lower foreign tariff allows home exporting firms to increase their prices, while equation (5) implies that a lower tariff in the home country induces home import-competing firms to reduce their prices in order to preserve market share. Note that this specification implicitly assumes the absence of price discrimination - domestic and foreign firms each sell their products at the same pre-tariff prices whether they are sold at home or exported. This is not necessarily realistic, but simplifies the analysis by restricting the number of different goods prices that have to be considered in evaluating real factor prices.

${ }^{15}$ It might be thought that equations (6) and (7) in combination with (4) and (5) overdetermine the mark-ups, but this is not the case because (4) and (5) pertain only to the pass-through of foreign prices into domestic prices but, in the presence of oligopoly and positive profits, are not sufficient to determine unit factor costs or (equivalently) markups. See the discussion of the two types of pass-through in the model, below.

${ }^{16}$ Analogous measures of home competitiveness have been used by (or are implicit in) Blecker (1989), Feenstra (1989), and Arestis and Milberg (1993-94). In principle, it might be argued that mark-ups should be determined in relation to relative unit costs (foreign-home), rather than the ratio of foreign prices to home unit costs, but this would require modeling the simultaneous determination of foreign mark-ups and pass-through, which we elide here based on the small country assumption. Also, home firms might lack information on foreign costs, but can observe foreign prices. Note that perfect competition (zero profits) is the special case in which $\Phi_{j}=1$ and $\alpha_{j}=0$, while a positive but rigid mark-up is the case in which $\Phi_{j}>1$ and $\alpha_{j}=0(j=1,2)$. Also note that both $\Phi_{j}$ and $\alpha_{j}(j=1,2)$ may reflect, among other factors, the ease or difficulty of domestic entry.
} 
Similarly, in the import-competing sector 2 , the home country mark-up is determined by

$$
1+\phi_{2}=\Phi_{2}\left(T_{2} p_{2}^{*} / c_{2}\right)^{\alpha_{2}}, \quad \Phi_{2} \geq 1,0 \leq \alpha_{2}<1
$$

where $\Phi_{2}$ is a constant reflecting other (exogenous) determinants of the sector's mark-up, and $\alpha_{2}$ is the elasticity of the mark-up factor with respect to the home cost competitiveness ratio for good 2, $T_{2} p_{2}^{*} / c_{2}$. Thus, when import-competing goods become more cost competitive (for example, because foreign prices rise or home tariffs are raised), domestic producers of these goods increase their mark-ups. We assume that the elasticities of the mark-up factors with respect to the cost competitiveness of home goods $\alpha_{j}(j=1,2)$ are constant for simplicity.

For mathematical convenience, we convert these equations into growth rate form and solve the model using an extended version of the famous Jones (1965) algebra. ${ }^{17}$ Changes in the prices of home goods (varieties) are obtained directly from logarithmic differentiation of (4) and (5), assuming that the $B_{j}(j=1,2)$ are constants:

$$
\begin{aligned}
& \hat{p}_{1}=\left(1-\beta_{1}\right)\left(\hat{p}_{1}^{*}-\hat{T}_{1}^{*}\right) \\
& \hat{p}_{2}=\left(1-\beta_{2}\right)\left(\hat{p}_{2}^{*}+\hat{T}_{2}\right)
\end{aligned}
$$

where a " $»$ " indicates an instantaneous growth rate or proportional rate of change. Thus, home prices rise if foreign prices are increasing, or if the foreign tariff on exports is lowered, or the home tariff on imports is raised, but in each case there is partial pass-through into domestic prices as long as $0<\beta_{j}<1$.

Using equations (1), (2), and (4) through (7), on the assumption that the $B_{j}$ and $\Phi_{j}(j=1$, 2) are constants, the proportional changes in unit factor costs are:

$$
\hat{c}_{1}=A_{1}\left(\hat{p}_{1}^{*}-\hat{T}_{1}^{*}\right)
$$

\footnotetext{
${ }^{17}$ The model solutions in levels are given in the Appendix.
} 


$$
\hat{c}_{2}=A_{2}\left(\hat{p}_{2}^{*}+\hat{T}_{2}\right)
$$

where $A_{j}=\frac{1-\alpha_{j}-\beta_{j}}{1-\alpha_{j}} \leq 1$ (assuming the further restriction that $\alpha_{j}+\beta_{j}<1$ ). Changes in markup rates of firms are then obtained from equations (8) through (11), and can be written as:

$$
\begin{aligned}
& \hat{p}_{1}-\hat{c}_{1}=\left(\frac{\alpha_{1} \beta_{1}}{1-\alpha_{1}}\right)\left(\hat{p}_{1}^{*}-\hat{T}_{1}^{*}\right) \\
& \hat{p}_{2}-\hat{c}_{2}=\left(\frac{\alpha_{2} \beta_{2}}{1-\alpha_{2}}\right)\left(\hat{p}_{2}^{*}+\hat{T}_{2}\right)
\end{aligned}
$$

The mark-up rate rises (i.e., the price increases proportionally more than unit factor costs) in each sector if the tariff-adjusted foreign price increases, and falls if the tariff-adjusted foreign price decreases, provided that there is partial pass-through of the foreign price change or tariff change into domestic prices (i.e., $\left.0<\beta_{j}<1\right)$ and the mark-up is flexible $\left(0<\alpha_{j}<1\right)$.

In effect, there are really two different kinds of pass-through in this model: pass-through into domestic prices, which depends only on the $\beta_{j}$ parameters, and pass-through into domestic factor costs and mark-ups, which depends on both the $\alpha_{j}$ and $\beta_{j}$ parameters. In terms of causality, exogenous changes in tariff rates or foreign prices lead to less-than-proportional changes in prices of home goods via (8) and (9), and then to changes (also less-than-proportional) in unit factor costs via (10) and (11) and mark-up rates and profit shares via (12) and (13) plus the definition of $\pi$.

To solve for the changes in factor prices $\hat{w}$ and $\hat{q}$, we must use a simultaneous equations approach. Logarithmic differentiation of the cost functions $c_{j}(w, q)$ yields

$$
\begin{aligned}
& \hat{c}_{1}=\theta_{L 1} \hat{w}+\theta_{N 1} \hat{q} \\
& \hat{c}_{2}=\theta_{L 2} \hat{w}+\theta_{N 2} \hat{q}
\end{aligned}
$$


where $\theta_{i j}$ is the share of factor $i$ in the unit cost of good $j$ (thus, $\theta_{L j}=w L_{j} / c_{j}$ and $\theta_{N j}=q N_{j} / c_{j}$ ).

Combining equations (10) and (11) with (14) and (15), the resulting pair of equations can be expressed in matrix form as

$$
\left[\begin{array}{c}
A_{1}\left(\hat{p}_{1}^{*}-\hat{T}_{1}^{*}\right) \\
A_{2}\left(\hat{p}_{2}^{*}+\hat{T}_{2}\right)
\end{array}\right]=\left[\begin{array}{ll}
\theta_{L 1} & \theta_{N 1} \\
\theta_{L 2} & \theta_{N 2}
\end{array}\right]\left[\begin{array}{l}
\hat{w} \\
\hat{q}
\end{array}\right]
$$

and the solution for factor price changes is

$$
\left[\begin{array}{l}
\hat{w} \\
\hat{q}
\end{array}\right]=\frac{1}{|\boldsymbol{\theta}|}\left[\begin{array}{cc}
\theta_{N 2} & -\theta_{N 1} \\
-\theta_{L 2} & \theta_{L 1}
\end{array}\right]\left[\begin{array}{c}
A_{1}\left(\hat{p}_{1}^{*}-\hat{T}_{1}^{*}\right) \\
A_{2}\left(\hat{p}_{2}^{*}+\hat{T}_{2}\right)
\end{array}\right]
$$

where $\theta$ is the $2 \times 2$ matrix on the RHS of (16). ${ }^{18}$ The determinant of this matrix is $|\theta|=\theta_{L 1} \theta_{N 2}-$ $\theta_{L 2} \theta_{N 1}$, which is positive if good 1 is $L$-intensive $\left(\theta_{L 1} / \theta_{N 1}>\theta_{L 2} / \theta_{N 2}\right)$ and negative if good 1 is $N$-intensive $\left(\theta_{L 1} / \theta_{N 1}<\theta_{L 2} / \theta_{N 2}\right)$. Given that $\theta_{L 1}+\theta_{N 1}=1$ and $\theta_{L 2}+\theta_{N 2}=1$, it can easily be shown that $|\boldsymbol{\theta}|=\theta_{\mathrm{L} 1}-\theta_{\mathrm{L} 2}=\theta_{N 2}-\theta_{N 1}$. For the sake of illustration, and without loss of generality, we assume that good 1 is $L$-intensive, which implies $|\theta|=\theta_{L 1}-\theta_{L 2}=\theta_{N 2}-\theta_{N 1}>0$.

From (17), the solutions for the factor-price changes $\hat{w}$ and $\hat{q}$ are:

$$
\begin{gathered}
\hat{w}=\frac{A_{1} \theta_{N 2}\left(\hat{p}_{1}^{*}-\hat{T}_{1}^{*}\right)-A_{2} \theta_{N 1}\left(\hat{p}_{2}^{*}+\hat{T}_{2}\right)}{\theta_{N 2}-\theta_{N 1}} \\
\hat{q}=\frac{-A_{1} \theta_{L 2}\left(\hat{p}_{1}^{*}-\hat{T}_{1}^{*}\right)+A_{2} \theta_{L 1}\left(\hat{p}_{2}^{*}+\hat{T}_{2}\right)}{\theta_{L 1}-\theta_{L 2}}
\end{gathered}
$$

which can be written as

$$
\hat{w}=A_{1}\left(\hat{p}_{1}^{*}-\hat{T}_{1}^{*}\right)+\frac{\theta_{N 1}\left[A_{1}\left(\hat{p}_{1}^{*}-\hat{T}_{1}^{*}\right)-A_{2}\left(\hat{p}_{2}^{*}+\hat{T}_{2}\right)\right]}{\theta_{N 2}-\theta_{N 1}}
$$

\footnotetext{
${ }^{18}$ Equation (17) reduces to the conventional S-S solution if $A_{1}=A_{2}=1$, which would hold if home and foreign goods were perfect substitutes $\left(\beta_{j}=0\right)$, regardless of whether the mark-up was flexible (i.e., even if $\alpha_{j}>0$ ), because then there would be full pass-through into both prices and factor costs (since, with domestic prices always equal to tariff-adjusted foreign prices, mark-ups would not actually change).
} 


$$
\hat{q}=A_{2}\left(\hat{p}_{2}^{*}+\hat{T}_{2}\right)-\frac{\theta_{L 2}\left[A_{1}\left(\hat{p}_{1}^{*}-\hat{T}_{1}^{*}\right)-A_{2}\left(\hat{p}_{2}^{*}+\hat{T}_{2}\right)\right]}{\theta_{L 1}-\theta_{L 2}}
$$

Because of the complexity of (20) and (21), we will consider a series of special cases in order to illuminate their implications. First, we consider an exogenous increase in the price of the foreign variety of good 1; then, we will consider equal-proportional tariff reductions in both sectors.

\subsection{An increase in the foreign price}

Consider first an increase in the price of the foreign variety of good 1 ( $\hat{p}_{1}^{*}>0$ ), holding the price of the foreign variety of good 2 and both tariff rates constant $\left(\hat{T}_{1}^{*}=\hat{p}_{2}^{*}=\hat{T}_{2}=0\right)$. We know from

(8) and (9) that $\hat{p}_{1}^{*}>\hat{p}_{1}=\left(1-\beta_{1}\right) \hat{p}_{1}^{*}>0=\hat{p}_{2}$. By equation (12), the mark-up rate in sector 1 rises (this can also be seen by comparing equations 8 and 10 , and noting that $1-\beta_{j}>A_{j}$ ), while by (13) the mark-up in sector 2 is unaffected. We can also infer from (21) that $\hat{q}<0$, and therefore $\hat{q}<0=\hat{p}_{2}<\hat{p}_{1}$, so the owners of $N$ lose absolutely in terms of either good, 1 or 2 . Equation (20) implies that $\hat{w}>0$, which also implies $\hat{w}>\hat{p}_{2}$, so $L$-workers definitely gain in terms of the imported good 2. However, in this model—unlike the traditional S-S model—it is ambiguous whether $L$-workers (owners of the factor used intensively in the good that increased in price) gain or lose in terms of that good, i.e., whether there is a magnification effect in the sense that the wage rises more than proportionally to the price of good 1.

Recalling that there is two-way trade in nationally differentiated goods, so home workers consume both domestic and foreign varieties of good 1, note that (20) combined with (8) implies (after much manipulation) that the real wage in terms of the home variety of good 1 rises (i.e., $\left.\hat{w}>\hat{p}_{1}\right)$ if and only if $\alpha_{1} \beta_{1} /\left[\left(1-\alpha_{1}\right)\left(1-\beta_{1}\right)\right]<\theta_{N 1} / \theta_{N 2}$, while (20) implies that the real wage in 
terms of the foreign variety rises (i.e., $\left.\hat{w}>\hat{p}_{1}^{*}\right)$ if and only if $\beta_{1} /\left(1-\alpha_{1}\right)<\theta_{N 1} / \theta_{N 2}$. Recalling that $\alpha_{1}$ reflects the degree of mark-up adjustment and $\beta_{1}$ reflects the degree of product differentiation, the higher are these two parameters, the more partial is the pass-through of the foreign price increase into domestic factor costs, and the less likely it is that the magnification effect holds in regard to the real wage in terms of good 1 , whether of the domestic or imported variety. Also note that $\theta_{N 1} / \theta_{N 2}<1$ since good 1 is $L$-intensive, so this ratio is lower if the gap in factor intensities between the industries is greater. If the magnification effect does not hold, then $L$ workers gain only if they consume relatively large quantities of good 2 and may lose if they consume relatively large quantities of good 1 - the more so if they consume a lot of the foreign variety, whose price increases by more than the domestic variety.

Putting these results together, we can see that any of the following sets of inequalities may hold in this situation:

$$
\begin{aligned}
& \hat{w}>\hat{p}_{1}^{*}>\hat{p}_{1}>\hat{p}_{2}=0>\hat{q} \\
& \hat{p}_{1}^{*}>\hat{w}>\hat{p}_{1}>\hat{p}_{2}=0>\hat{q} \\
& \hat{p}_{1}^{*}>\hat{p}_{1}>\hat{w}>\hat{p}_{2}=0>\hat{q} .
\end{aligned}
$$

Thus, contrary to the standard S-S theorem (in which only 22a could hold, with $\hat{p}_{1}^{*}=\hat{p}_{1}$ ), it is possible for both primary factor owners to lose from an increase in the price of the exported good, if pass-through is very partial and if the owners of the factor used intensively in producing the good that increased in price consume relatively large quantities of that good (especially the foreign variety). ${ }^{19}$

These results may be summarized in the Stolper-Samuelson-Kalecki (SSK) theorem:

\footnotetext{
${ }^{19}$ Analogous results obtain when the price of the foreign variety of the imported good 2 increases, holding the price of the foreign variety of good 1 and both tariff rates constant.
} 
Assuming that oligopolistic firms in a small price-taking country produce two goods that are imperfect substitutes for the same foreign goods using CRS technology, an increase in the price of a foreign good causes a smaller rise in the domestic price of the same good, and increases the mark-up rate (price-cost margin) and profit share in the industry which produces that good. The real price of the primary factor of production used intensively in the production of the other good definitely falls, while the real price of the factor used intensively in the good that increased in price may either rise or fall depending on the extent of partial pass-through of the foreign price change into prices and factor costs and the proportions in which this factor's owners consume the two goods.

This theorem is contrasted with the standard S-S theorem in Figure 2. If, as in the conventional S-S analysis, the goods were perfect substitutes and the goods markets were perfectly competitive, then the foreign price curves $p_{1}{ }^{*}$ and $p_{2}{ }^{*}$ would also represent unit factor costs in the home country. If $p_{1}{ }^{*}$ rises to $p_{1}{ }^{\prime}$ while $p_{2}{ }^{*}$ remains constant, factor prices would shift from the levels marked by a superscript "0" to the levels marked by a superscript " 3 .” In this case, the proportional rise in $w$ (from $w^{0}$ to $w^{3}$ ) would be greater than the proportional rise in $p_{1}{ }^{*}$, signifying a magnification effect for the factor used intensively in the good whose price increased ( $L$ in this example).

[Figure 2 about here]

However, with positive profit mark-ups and differentiated products, the home country prices $p_{1}$ and $p_{2}$ differ from the foreign prices $p_{1}{ }^{*}$ and $p_{2}{ }^{*}$ (home prices are not shown in Figure 2 to avoid cluttering the diagram), and the unit cost curves are at the levels $c_{1}$ and $c_{2}$ (which must be below the home price curves, although they could be either above or below the foreign price curves). ${ }^{20}$ Assuming partial pass-through into factor costs, the unit cost curve for industry 1 shifts up (from $c_{1}$ to $c_{1}{ }^{\prime}$ ) by a smaller proportion than the rise in either $p_{1}$ or $p_{1}{ }^{*}$ (compare equations 8 and 10 , and recall that $A_{1}<1-\beta_{1}$ ). Then, when $w$ rises from $w^{1}$ to $w^{2}$, even though this change in

\footnotetext{
${ }^{20}$ In drawing Figure 2 we have assumed that the domestic unit factor cost curves are below the foreign price curves, although this is not strictly necessary if home varieties are superior in quality. What is critical to the analysis here is that that the shifts in the unit cost curves are proportionally smaller than the shifts in the corresponding price curves.
} 
$w$ is proportionally greater than the change in $c_{1}$, we cannot be sure whether the change in $w$ is proportionally greater or less than the changes in $p_{1}$ and $p_{1}{ }^{*}$. The result is what we call an “attenuated Stolper-Samuelson effect” (the smaller shift from $w^{1}$ to $w^{2}$ ) instead of the "traditional Stolper-Samuelson magnification effect” (the larger shift from $w^{0}$ to $w^{3}$ ). The more partial is the pass-through into factor costs, the smaller will be the shift in $c_{1}$, and hence the greater is the likelihood that $L$-workers could lose in terms of good 1 (either foreign or domestic varieties).

\subsection{Reciprocal trade liberalization}

Suppose that there are equal-proportional tariff reductions in the home and foreign countries, i.e., $\hat{T}_{1}^{*}=\hat{T}_{2}=\hat{T}<0$, holding the prices of the foreign varieties constant $\left(\hat{p}_{1}^{*}=\hat{p}_{2}^{*}=0\right) .{ }^{21}$ Clearly, from (8) and (9), the changes in home prices are $\hat{p}_{1}=-\left(1-\beta_{1}\right) \hat{T}>0>\hat{p}_{2}=\left(1-\beta_{2}\right) \hat{T}$ so there will be partial pass-through of the tariff reductions into domestic prices as long as home and foreign goods are imperfect substitutes $\left(\beta_{j}>0, j=1,2\right)$. If, in addition, mark-ups are sensitive to international competitiveness $\left(\alpha_{j}>0, j=1,2\right)$, then equations (12) and (13) show that the markup rate will rise for firms in industry 1 (the export sector) and fall in industry 2 (the importcompeting sector)—and profit shares will adjust in the same directions by the definition of $\pi_{j}$.

Assuming $\hat{T}_{1}^{*}=\hat{T}_{2}=\hat{T}<0$ in (20) and (21), the changes in factor prices can be reduced to

$$
\hat{w}=\frac{-\left(A_{1} \theta_{N 2}+A_{2} \theta_{N 1}\right) \hat{T}}{\theta_{N 2}-\theta_{N 1}}>0
$$

\footnotetext{
${ }^{21}$ If the foreign producers also have partial pass-through of the tariff changes, they will adjust the prices of their varieties to the tariff reductions. In that case, what would matter to the home country would be the net changes in the tariff-adjusted foreign prices, $\hat{p}_{1}^{*}-\hat{T}_{1}^{*}$ and $\hat{p}_{2}^{*}+\hat{T}_{2}^{*}$. However, incorporating foreign price responses into this modeling framework is left for future research.
} 


$$
\hat{q}=\frac{\left(A_{2} \theta_{L 1}+A_{1} \theta_{L 2}\right) \hat{T}}{\theta_{L 1}-\theta_{L 2}}<0
$$

Thus, $L$ definitely gains relative to $N$, but with domestic prices of both goods changing, it is not obvious whether real factor prices rise or fall in terms of both goods or not. Evidently, the real price of the factor used intensively in exported goods rises in terms of the imported good, i.e., $w / p_{2}$ and $w / T p_{2}{ }^{*}$ both increase. Also, the real price of the factor used intensively in importcompeting production definitely falls in terms of the exported good, i.e., $q / p_{1}$ and $q / p_{1}{ }^{*}$ both rise. However, it is not clear whether the changes in real factor prices are "absolute” or magnified, in the sense that the price of each factor rises or falls in terms of the good in which it is used intensively, i.e., does $w / p_{1}$ increase and does $q / p_{2}$ or $q / T p_{2}{ }^{*}$ decrease? ${ }^{22}$

Whether $w / p_{1}$ increases depends on whether $\hat{w}=\frac{-\left(A_{1} \theta_{N 2}+A_{2} \theta_{N 1}\right) \hat{T}}{\theta_{N 2}-\theta_{N 1}}>\hat{p}_{1}=-\left(1-\beta_{1}\right) \hat{T}$, or $\frac{A_{1} \theta_{N 2}+A_{2} \theta_{N 1}}{\theta_{N 2}-\theta_{N 1}}>1-\beta_{1}$, which can be expressed as $\alpha_{1} \beta_{1} /\left(A_{2}+1-\beta_{1}\right)\left(1-\alpha_{1}\right)<\theta_{N 1} / \theta_{N 2}$. Since the denominator of the ratio on the LHS must be positive, the higher are $\alpha_{1}$ (the sensitivity of sector 1 mark-ups to international competitiveness) and $\beta_{1}$ (the degree of product differentiation for good 1), the more partial is the pass-through into factor costs in the sector in which $L$ is used intensively, and also the lower is the ratio $\theta_{N 1} / \theta_{N 2}$ (i.e., the greater the gap in factor intensities between the two sectors, since $\theta_{N 1}<\theta_{N 2}$ ), the greater is the likelihood that these inequalities will be reversed and $w / p_{1}$ will decrease. In the latter situation, whether $L$-workers gain or lose will depend on their consumption bundle, contrary to the S-S theorem in which it does not matter which goods the factor owners consume.

Similar considerations pertain to whether $q / p_{2}$ falls, which analogously depends on

\footnotetext{
${ }^{22}$ The results for $w / p_{1}{ }^{*}$ are unambiguous, since $w$ rises while $p_{1}{ }^{*}$ is unchanged and there is no tariff by assumption.
} 
whether $\alpha_{2} \beta_{2} /\left(A_{1}+1-\beta_{2}\right)\left(1-\alpha_{2}\right)<\theta_{L 2} / \theta_{L 1}$. The higher are $\alpha_{2}$ and $\beta_{2}$ (i.e., the more partial the pass-through into factor costs in sector 2), and the lower is $\theta_{L 2} / \theta_{L 1}$ (i.e., the greater the gap in factor intensities, since $\theta_{\mathrm{L} 2}<\theta_{\mathrm{L} 1}$ ), the more likely that this inequality could be reversed and $q / p_{2}$ would rise. Also, $q / T p_{2}{ }^{*}$ falls if and only if $\beta_{2} /\left(A_{1}+1\right)\left(1-\alpha_{2}\right)<\theta_{L 2} / \theta_{L 1}$. Sufficiently high values of $\beta_{2}$ or $\alpha_{2}$, or a low enough ratio $\theta_{L 2} / \theta_{L 1}$, could reverse this inequality and allow $N$-owners to gain in terms of imports of good 2. If either of these inequalities is reversed, then the overall real gains or losses to $\mathrm{N}$-owners would depend on their consumption bundle, contrary to S-S.

All these results may be summarized in the reciprocal trade liberalization corollary to the SSK theorem:

Under the same assumptions as for the SSK theorem, if both the home and foreign countries reduce their import tariffs by the same percentage, the mark-up rate (price-cost margin) and profit share rise in the home export industry and fall in the home import-competing industry. The real price of the factor used intensively in the export industry definitely rises in terms of the imported good, but may either rise or fall in terms of the exported good, while the real price of the factor used intensively in the import-competing industry definitely falls in terms of the exported good but may either rise or fall in terms of the imported good. If the pass-through of the tariff reductions into factors costs is sufficiently partial, the effects on real factor prices will depend on the proportions in which the factor owners consume the two goods.

[Figure 3 about here]

The effects of reciprocal trade liberalization on prices of domestic factors and domestically produced goods are illustrated in Figure 3. The domestic price of good 1 rises while the domestic price of good 2 falls, and the unit factor costs shift in the same direction as the price for each good but (assuming partial pass-through of the tariff cuts into factor costs) by a smaller proportion. The changes in factor prices with positive mark-ups and partial pass-through (from $w^{1}$ to $w^{2}$ and $q^{1}$ to $q^{2}$ ) are smaller than they would be, if mark-ups were zero and there was full pass-through (from $w^{0}$ to $w^{3}$ and $q^{0}$ to $q^{3}$ ). Although it may not be visually obvious, it is possible 
for the increase from $w^{1}$ to $w^{2}$ to be proportionally smaller than the increase in the price of good 1 (from $p_{1}$ to $p_{1}{ }^{\prime}$ ) and for the decrease from $q^{1}$ to $q^{2}$ to be proportionally smaller than the decrease in the price of good 2 (from $p_{2}$ to $p_{2}{ }^{\prime}$ ). This would require a relatively large difference in factor intensities between the two sectors (so that $c_{1}$ would be much steeper than $c_{2}$ ) and relatively little (more partial) pass-through (so that the shifts in $c_{1}$ and $c_{2}$ would be relatively small).

\section{TRADE IN INTERMEDIATE GOODS AND OFFSHORING}

As emphasized in several studies cited earlier, some of the impact of international trade on factor prices may come through “outsourcing” or “offshoring,” i.e., vertical trade in intermediate inputs, within a given industry, rather than trade in finished products. ${ }^{23}$ This section briefly addresses how the analysis of trade with imported intermediate goods can be modified to incorporate oligopolistic profits and differentiated products, similar to the analysis in the previous section. For this purpose, we use a very simple model from Feenstra (2004, pp. 106-11) in which there is one final good, $z$, that is produced using inputs of two intermediate goods, 1 and 2 (for simplicity, no other inputs are used in final goods production). The intermediate goods in turn are produced using only inputs of the primary factors $L$ and $N .^{24}$

Home and foreign intermediate goods are assumed to be perfect substitutes in production and to be sold in perfectly competitive markets, while_-and here we differ from Feenstra—-the final good is assumed to be differentiated and produced by oligopolistic firms with positive mark-ups. Both final goods and intermediate goods are traded and, for simplicity, we assume

\footnotetext{
${ }^{23}$ The term "offshoring" is often preferred by economists to the more popular "outsourcing," because the latter can also refer to a situation in which a firm contracts out for inputs or services domestically rather than importing them.

${ }^{24}$ Feenstra includes capital $(K)$ as an input into intermediate goods, but it is irrelevant to his results since he assumes that its cost share is the same in both goods $\left(\theta_{K 1}=\theta_{K 2}\right)$. We simplify by omitting capital here.
} 
free trade with no tariffs or other barriers (so $T_{j}=1, j=1,2, z$ ). Thus, the prices of home and foreign varieties of intermediate goods 1 and 2 must be equal (i.e., $p_{1}=p_{1}{ }^{*}$ and $p_{2}=p_{2}{ }^{*}$ ), but the prices of home and foreign varieties of the final good $z$ may differ $\left(p_{z} \neq p_{z}{ }^{*}\right.$ in general).

The production functions are as follows:

$$
\begin{aligned}
& y_{z}=f_{z}\left(y_{1}-x_{1}, y_{2}-x_{2}\right) \\
& y_{j}=f_{j}\left(L_{j}, N_{j}\right), \quad j=1,2
\end{aligned}
$$

where $x_{j}$ is net exports of intermediate good $j$. The price-cost equation for final goods incorporates a positive profit mark-up $\phi_{z}>0$,

$$
p_{z}=\left(1+\phi_{z}\right)\left[p_{1} a_{1 z}+p_{2} a_{2 z}\right]=\left(1+\phi_{z}\right) c_{z}\left(p_{1}, p_{2}\right)
$$

while the price-cost equations for the intermediate goods reflect the zero profit assumption

$$
p_{j}=w a_{L j}+q a_{N j}=c_{j}(w, q), \quad j=1,2 .
$$

Assuming free trade in intermediate goods in a small, price-taking country, the home prices of intermediates are pinned down by the prices of the foreign perfect substitutes (recall $p_{1}=p_{1}{ }^{*}$ and $p_{2}=p_{2}^{*}$ ), which in turn uniquely determine the unit factor cost of producing final goods, $c_{z}\left(p_{1}{ }^{*}, p_{2}{ }^{*}\right) .{ }^{25}$ The profit mark-up on final goods is variable, however.

In this setting, because input costs are effectively given, having firms in the final goods sector set both prices (as in equations 4 and 5) and mark-ups (as in equations 6 and 7) would overdetermine the model. We choose to use a price-setting equation similar to (4) or (5): ${ }^{26}$

$$
p_{z}=B_{z}\left(p_{z}^{*}\right)^{1-\beta_{z}}, \quad B_{z}>0,0 \leq \beta_{z}<1
$$

where the higher is $\beta_{z}$, the more differentiated are home and foreign final goods. Combining (27)

\footnotetext{
${ }^{25}$ Under conventional assumptions, the input-output coefficients for the final good are also uniquely determined by the world prices of the intermediate inputs: $a_{1 z}=a_{1 z}\left(p_{1}{ }^{*}, p_{2}{ }^{*}\right)$ and $a_{2 z}=a_{2 z}\left(p_{1}{ }^{*}, p_{2}{ }^{*}\right)$.

${ }^{26}$ This specification means that the mark-up in the final goods sector adjusts endogenously. Qualitatively similar results are obtained using an equation like (6) or (7) for mark-up setting, and allowing the final goods price to adjust.
} 
and (29), the equilibrium mark-up factor can be solved for as follows:

$$
\left(1+\phi_{z}\right)=\frac{B_{z}\left(p_{z}^{*}\right)^{1-\beta_{z}}}{p_{1}^{*} a_{1 z}+p_{2}^{*} a_{2 z}}=\frac{B_{z}\left(p_{z}^{*}\right)^{1-\beta_{z}}}{C_{z}\left(p_{1}^{*}, p_{2}^{*}\right)} .
$$

Converting to growth rates and assuming that $B_{z}$ is a constant, the solution for the change in the mark-up can be written as

$$
\hat{p}_{z}-\hat{c}_{z}=\left(1-\beta_{z}\right) \hat{p}_{z}^{*}-\left[\theta_{1 z} \hat{p}_{1}^{*}+\theta_{2 z} \hat{p}_{2}^{*}\right]
$$

where $\theta_{\mathrm{iz}}$ is the share of intermediate input $i$ in the unit cost of final good $z$, and $\theta_{1 z}+\theta_{2 z}=1$.

Now, suppose that, as a result of the entry of several large, labor-abundant countries into the global economy, the world price of the $L$-intensive intermediate good $p_{1}{ }^{*}$ falls $\left(\hat{p}_{1}^{*}<0\right)$. Assuming (initially) that the world price of final goods $p_{z}{ }^{*}$ stays constant, ${ }^{27}$ the fall in $p_{1}{ }^{*}$ increases the mark-up in the home final goods sector in proportion to the share of intermediate good 1 in unit costs for final goods production, $-\theta_{1 z} \hat{p}_{1}^{*}>0$.

With regard to the primary factors, it is easy to see that the fall in $p_{1}{ }^{*}$ must also redistribute income relatively in favor of $N$ and against $L$. Converting the two equations (28) into growth rate form and subtracting one from the other, we obtain

$$
\hat{p}_{1}-\hat{p}_{2}=\left(\theta_{L 1}-\theta_{L 2}\right) \hat{w}-\left(\theta_{N 2}-\theta_{N 1}\right) \hat{q}=\left(\theta_{L 1}-\theta_{L 2}\right)(\hat{w}-\hat{q})
$$

since (assuming intermediate good 1 is $L$-intensive) $\theta_{L 1}-\theta_{L 2}=\theta_{N 2}-\theta_{N 1}>0$. This then solves for the change in the relative factor price:

$$
\hat{w}-\hat{q}=\frac{\hat{p}_{1}-\hat{p}_{2}}{\theta_{L 1}-\theta_{L 2}}
$$

which will be negative, since (in this example) $\hat{p}_{1}<0$ and $\hat{p}_{2}=0 .{ }^{28}$ This result does not depend

\footnotetext{
${ }^{27}$ The case in which the world price of final goods also falls will be discussed below.

${ }^{28}$ We do not deploy S-S-type matrix analysis here, because we have no need to determine how the changes in $w$ and $q$ relate to changes in the prices of goods 1 and 2, since in the present case the latter are intermediate goods that are
} 
on whether the home country is a net exporter or importer of either the intermediate good 1 or the final good $z$. Thus, this model is consistent with the stylized fact that skill premiums have increased in both countries that import less-skilled-labor-intensive intermediate goods (such as the US—-see the studies cited earlier) and countries that export them (such as Mexico—see Revenga and Montenegro, 1998; Hanson, 2004).

The preceding analysis of mark-ups assumes that the world price of final goods $p_{z}{ }^{*}$ remains constant when the world price of the $L$-intensive intermediate good $p_{1}{ }^{*}$ falls. If the entry of new labor-abundant nations into the global economy also reduces the world price of the final good $p_{z}{ }^{*}$, then according to (31) the net effect on the profit mark-up depends on the sign of $\left(1-\beta_{z}\right) \hat{p}_{z}^{*}-\theta_{1 z} \hat{p}_{1}^{*}$, where $\hat{p}_{1}^{*}, \hat{p}_{z}^{*}<0$. If the world prices of final goods and $L$-intensive intermediate goods fall by equal percentages (i.e., $\hat{p}_{1}^{*}=\hat{p}_{z}^{*}<0$ ), then mark-ups on final goods will increase if $\theta_{1 z}>1-\beta_{z}$ and decrease if $\theta_{1 z}<1-\beta_{z}$. Generally, the more the home and foreign final goods are differentiated (the higher is $\beta_{z}$ ), and the higher is the cost share of the $L$-intensive intermediates in final goods production $\left(\theta_{1 z}\right)$, the more likely it is that the mark-up on final goods will rise. ${ }^{29}$ Of course, the increase in the profit mark-up results only when the world price of the final good does not fall by a sufficient degree to offset the cost savings from cheaper intermediate inputs. However, if domestic profit mark-ups are squeezed as a result of lower foreign prices of final goods_ especially ones that are intensive in less-skilled labor — this only increases the incentives for domestic firms to source more of their $L$-intensive intermediate inputs from countries with lower less-skilled wages, $w$.

not consumed directly by factor owners. This part of the analysis is taken directly from Feenstra (2004, pp. 109-10), and is not affected by changes in final goods prices as discussed below.

${ }^{29}$ This result thus supports the argument of Milberg (2010) that large oligopolistic firms have been able to increase their profit margins via two complementary routes - cost-saving via offshoring of inputs on the one hand, and greater product differentiation (what he calls "customization of design") on the other-in the context of globalized supply chains. 


\section{CONCLUSIONS}

This paper has analyzed how international trade affects income distribution when firms are oligopolists that earn positive economic profits via mark-up pricing and sell nationally differentiated products that are imperfect substitutes for foreign goods, in a model that otherwise makes most of the standard assumptions required for the S-S theorem-especially, perfectly competitive factor markets with flexible factor prices and full employment. In this context, changes in tariff rates or foreign prices are only partially passed through into prices of domestically produced goods and payments to domestic factors of production. If the passthrough to factor payments is sufficiently partial in any given sector of the economy (as a result of adjustments in mark-ups as well as goods prices), then the factor used intensively in that sector may not experience a S-S magnification effect in response to a change in either tariff rates or foreign prices, i.e., the real price of a factor may possibly fall (rise) when the relative price of the good in which it is used intensively rises (falls). Contrary to S-S, the gains or losses to that factor may depend on the consumption bundle of its owners, and reversals of S-S results occur precisely when the owners of the factor used intensively in a good that rises in relative price consume large amounts of that good (domestic and foreign varieties).

Viewing firms' profits as generated by oligopolistic mark-up pricing in the presence of excess capacity, then the interests of firms depend on whether they produce exported or importcompeting goods, rather than whether the country is capital-abundant or capital-scarce, or whether it exports or imports the capital-intensive good. ${ }^{30}$ In this situation, trade liberalization is

\footnotetext{
${ }^{30}$ If factor $N$ is physical capital that is owned by the firms, then the total returns to the firms would be the sum of the implicit rents they receive for the services of their capital plus the rents due to their oligopolistic pricing, so the
} 
likely to reduce oligopolistic profits for firms in import-competing industries and increase profits for firms in export industries. This result resembles the outcome in a specific factors model in which particular types of capital are immobile in each industry, although the reason why the interests of firms align this way in the present model is different from the reason why the same result obtains in the specific factors model. ${ }^{31}$

In this context, whether firms (business interests) in general are more likely to support protectionist or free-trade policies depends fundamentally on two things: (1) the relative weight of export and import-competing industries in the national economy; and (2) the degree to which firms (in any industry, whether exporting or import-competing) are able to import cheaper intermediate goods via offshoring. Historically, in early industrial capitalism, offshoring of inputs was difficult due to "natural” barriers to trade (e.g., high costs of transportation and slow communications), and many tradable goods industries were import-competing, so industrial interests in most countries (other than Britain, the first country to industrialize) tended to support protectionism. However, in recent decades, as export interests have gained ascendancy and offshoring has (for various well-known reasons ${ }^{32}$ ) become much easier, the preponderance of business interests in many countries has shifted in favor of trade liberalization.

Moreover, trade liberalization creates a self-supporting dynamic: since trade liberalization induces the expansion of export activities and the shrinkage of import-competing

interests of owners of firms and capital (assuming they are the same, i.e., the firms own the capital) would depend on both what happens to both the imputed rents for capital services and the oligopolistic rents of the firms.

${ }^{31}$ In the specific factors model, the scarcity rents of immobile factors increase in export sectors where production increases and decrease in import-competing sectors where production decreases as a result of trade liberalization. In the present model, oligopolistic pricing-to-market behavior in the presence of barriers to entry and product differentiation allows firms to increase mark-ups on exported goods and induces them to decrease mark-ups on import-competing goods when trade barriers are reduced.

32 These reasons include the industrial development of lower-wage, developing countries and the revolutions in communications, transportation, and information technology that have facilitated offshore production, all of which have been accelerated by the global mobility of capital and technology, in addition to trade liberalization policies. 
activities and also makes it less costly to import intermediate goods, it tends to increase the weight of the very business interests that are likely to benefit from further liberalization. This approach can therefore help to explain why corporate business interests generally support trade liberalization today, in capital-scarce countries as well as in capital-rich ones (aside from occasional, sector-specific pleadings for protection or subsidies).

The analysis in this paper was deliberately conducted with simple models that were intended to highlight contrasts with the conventional S-S theorem. As a result, the analysis is necessarily limited in several respects, which imply the need to extend the approach in various directions. We used a two-good, two-factor model, but the model could be extended to a multigood, multi-factor setting. The model assumed a small, price-taking country, and focused on partial pass-through into domestic prices, but the analysis could be extended to two (or more) large countries in which each country's trade policies can affect foreign export prices. We implicitly assumed either a single representative firm or a set of identical firms in each domestic industry, but we could explore oligopolistic behavior in a model of trade with heterogeneous firms distinguished by different cost functions à la Melitz (2003) or goods differentiated by firm rather than by national origin. The model assumed that factor markets were perfectly competitive, but imperfectly competitive labor markets in which wages are determined by bargaining power also need to be considered-and in that context, the levels of factor employment could also be made endogenous. Also, we assumed fixed parameters (constant elasticities) to represent the partial pass-through and flexible mark-up behavior of the firms. The behavioral underpinnings of these relationships (optimizing or otherwise) as well as cases with non-constant elasticities could be further explored. Finally, empirical research is needed to test the implications of the models in this paper. In particular, empirical tests could focus on the 
results for profit mark-ups or price-cost margins, as well as the implication that S-S effects

should be weaker for factors used intensively in industries that exhibit more partial pass-through of tariff changes.

\section{APPENDIX: MODEL SOLUTIONS IN LEVELS}

Combining equations (1)-(2) and (4)-(7), the reduced-form solutions for unit factor costs in each industry in levels are as follows:

$$
\begin{aligned}
& c_{1}(w, q)=\left[\frac{B_{1}}{\Phi_{1}}\left(\frac{p_{1}^{*}}{T_{1}^{*}}\right)^{1-\alpha_{1}-\beta_{1}}\right]^{\frac{1}{1-\alpha_{1}}} \\
& c_{2}(w, q)=\left[\frac{B_{2}}{\Phi_{2}}\left(T_{2} p_{2}^{*}\right)^{1-\alpha_{2}-\beta_{2}}\right]^{\frac{1}{1-\alpha_{2}}} .
\end{aligned}
$$

Reduced form solutions for the mark-up factors in levels are obtained by using (4)-(5) and (A1)(A2) in (1)-(2) and solving for $\left(1+\phi_{j}\right)$, which after simplification yields

$$
\begin{aligned}
& 1+\phi_{1}=\left(\Phi_{1} / B_{1}^{\alpha_{1}}\right)^{\frac{1}{1-\alpha_{1}}}\left(p_{1}^{*} / T_{1}^{*}\right)^{\frac{\alpha_{1} \beta_{1}}{1-\alpha_{1}}} \\
& 1+\phi_{2}=\left(\Phi_{2} / B_{2}^{\alpha_{2}}\right)^{\frac{1}{1-\alpha_{2}}}\left(T_{2} p_{2}^{*}\right)^{\frac{\alpha_{2} \beta_{2}}{1-\alpha_{2}}} .
\end{aligned}
$$

Assuming that the factors $L$ and $N$ are mobile between industries and both goods are produced in equilibrium with no factor-intensity reversals, (A1) and (A2) simultaneously (and uniquely) determine the factor prices $w$ and $q$, with no information on factor supplies required. ${ }^{33}$

\footnotetext{
${ }^{33}$ This result is known as the "factor-price insensitivity lemma," i.e., factor prices do not depend on factor supplies ("endowments") in a free-trade equilibrium under these assumptions (Feenstra, 2004). In effect, we have generalized this lemma to the case in which unit factor costs do not coincide with goods prices.
} 


\section{REFERENCES}

Arestis, P., Milberg, W. (1993-94): 'Degree of monopoly, pricing, and flexible exchange rates', Journal of Post Keynesian Economics, 16 (2), pp. 167-88.

Berman, E., Bound, J., Griliches, Z. (1994): 'Changes in the demand for skilled labor within U.S. manufacturing: evidence from the annual survey of manufactures', Quarterly Journal of Economics, 109 (2), pp. 367-97.

Bernard, A. B., Jensen, J. B. (1997): 'Exporters, skill upgrading, and the wage gap', Journal of International Economics, 42 (1-2), pp. 3-31.

Bivens, L. J. (2006): 'Wages, profits, and rent-sharing in an open economy', International Review of Applied Economics, 20 (1), pp. 69-83.

Blanchflower, D. G., Oswald, A. J., Sanfey, P. (1996): 'Wages, profits, and rent-sharing', Quarterly Journal of Economics, 111 (1), pp. 227-51.

Blecker, R. A. (1989): 'International competition, income distribution, and economic growth', Cambridge Journal of Economics, 13 (3), pp. 395-412.

Brander, J. A., Krugman, P. R. (1983): ‘A reciprocal dumping model of international trade’, Journal of International Economics, 15 (3-4), pp. 313-23.

Brander, J. A., Spencer, B. J. (1984a): ‘Tariff protection and imperfect competition', in Kierzkowsi, H. (ed.), Monopolistic Competition and International Trade, Oxford University Press, New York.

Brander, J. A., Spencer, B. J. (1984b): ‘Trade warfare: tariffs and cartels', Journal of International Economics, 16 (3-4), pp. 227-42.

Castañeda Sabido, A., Mulato, D. (2006): 'Market structure: concentration and imports as determinants of industry margins’, Estudios Económicos, 21 (2), pp. 177-202.

Chacholiades, M. (1978): International Trade Theory and Policy, McGraw-Hill, New York.

Dornbusch, R. (1987): 'Exchange rates and prices’, American Economic Review, 77 (1), pp. $93-$ 106.

Dutt, A. K. (1988): 'Monopoly power and uneven development: Baran revisited', Journal of Development Studies, 24 (2), pp. 161-76.

Eaton, J., Grossman, G.M. (1986): 'Optimal trade policy and industrial policy under oligopoly', Quarterly Journal of Economics, 101 (2), pp. 383-406. 
Egger, H., Kreickemeier, U. (2009): 'Firm heterogeneity and the labor market effects of trade liberalization’, International Economic Review, 50 (1), pp. 187-216.

Eichner, A. S. (1976): The Megacorp and Oligopoly, Cambridge University Press, Cambridge.

Ethier, W. (1979): 'The theorems of international trade in time-phased economies', Journal of International Economics, 9 (2), pp. 225-38.

Feenstra, R. C. (1989): 'Symmetric pass-through of tariffs and exchange rates under imperfect competition: an empirical test', Journal of International Economics, 27 (1-2), pp. 25-45.

Feenstra, R. C. (2004): Advanced International Trade: Theory and Evidence, Princeton University Press, Princeton.

Feenstra, R. C., Hanson, G. H. (1996): 'Foreign investment, outsourcing, and relative wages', in Feenstra, R. C., Grossman, G. M., Irwin, D. A. (eds): The Political Economy of Trade Policy: Papers in Honor of Jagdish Bhagwati, MIT Press, Cambridge.

Feinberg, R. M. (1986): 'The interaction of foreign exchange and market power effects on German domestic prices’, Journal of Industrial Economics, 35 (1), pp. 61-70.

Feinberg, R. M. (1989): 'The effects of foreign exchange movements on U.S. domestic prices', Review of Economics and Statistics, 71 (3), pp. 505-11.

Goldberg, P. K., Knetter, M. M. (1996): 'Goods prices and exchange rates: what have we learned?’, Journal of Economic Literature, 35 (3), pp. 1243-72.

Grossman, G. M. (ed.) (1990): Imperfect Competition and International Trade, MIT Press, Cambridge.

Hanson, G. H. (2004): 'What has happened to wages in Mexico Since NAFTA? implications for hemispheric free trade', in Estevadeordal, A., et al. (eds): Integrating the Americas: FTAA and Beyond, Harvard University Press, Cambridge.

Harrison, A., McLaren, J., McMillan, M. (2011): 'Recent perspectives on trade and inequality', Annual Review of Economics, 3, pp. 261-89.

Heintz, J. (2006): 'Low-wage manufacturing and global commodity chains: a model in the unequal exchange tradition', Cambridge Journal of Economics, 30 (4), pp. 507-20.

Helpman, E., Krugman, P. R. (1985): Market Structure and Foreign Trade, MIT Press, Cambridge.

Jones, R. W. (1965): 'The structure of simple general equilibrium models', Journal of Political Economy, 73 (6), pp. 557-72. 
Jones, R. W. (1971): 'A three-factor model in theory, trade, and history', in Bhagwati, J. N. (ed.): Trade, Balance of Payments, and Growth: Essays in Honor of C. P. Kindleberger, NorthHolland, Amsterdam.

Kalecki, M. (1954): Theory of Economic Dynamics: An Essay on Cyclical and Long-Run Changes in Capitalist Economy, Unwin Allen, London. Reprinted: Monthly Review Press, New York, 1968.

Katz, L. F., Summers, L. H. (1989): 'Industry rents: evidence and implications’, Brookings Papers on Economic Activity: Microeconomics, 1989, pp. 209-90.

Krugman, P. R. (1979): 'Increasing returns, monopolistic competition, and international trade', Journal of International Economics, 9 (4), pp. 469-79.

Krugman, P. R. (2008): 'Trade and wages, reconsidered', Brookings Papers on Economic Activity, 2008 (1), pp. 103-37.

Lawrence, R. Z., Slaughter, M. J. (1993): 'Trade and American wages in the 1980s: giant sucking sound or small hiccup?’, Brookings Papers on Economic Activity, 1993 (2), pp. 161226.

Leamer, E. E. (1998): 'In search of Stolper-Samuelson linkages between international trade and lower wages’, in Collins, S. M. (ed.): Imports, Exports, and the American Worker, Brookings Institution, Washington.

Mallick, S., Marques, H. (2008): 'Passthrough of exchange rate and tariffs into import prices of India: currency depreciation versus import liberalization', Review of International Economics, 16 (4), pp. 765-82.

Mann, C. L. (1986): 'Prices, profit margins, and exchange rates', Federal Reserve Bulletin, 72 (6), pp. 366-79.

Marston, R. C. (1990): 'Pricing to market in Japanese manufacturing', Journal of International Economics, 29 (3-4), pp. 217-36.

Melitz, M. J. (2003): 'The impact of trade on intra-industry reallocations and aggregate industry productivity’, Econometrica, 71 (6), pp. 1695-725.

Melvin, J. R., Warne, R. D. (1973): 'Monopoly and the theory of international trade', Journal of International Economics, 3 (2), pp. 117-34.

Milberg, W. S. (2010): 'Pricing and profits under globalized production: a post-Keynesian perspective on U.S. economic hegemony’, in Lavoie, M., Rochon, L-P., Seccareccia, M. (eds): Money and Macrodynamics: Alfred Eichner and Post-Keynesian Economics, M. E. Sharpe, Armonk, NY. 
Milberg, W., Winkler, D. (2010): 'Financialisation and the dynamics of offshoring in the USA', Cambridge Journal of Economics, 34 (2), pp. 275-93.

Neary, J. P. (1978): 'Short-run capital specificity and the theory of international trade,' Economic Journal, 88 (351), pp. 488-510.

Nicita, A. (2009): 'The price effect of tariff liberalization: measuring the impact on household welfare', Journal of Development Economics, 89 (1), pp. 19-27.

Ohno, K. (1989): ‘Export pricing behavior of manufacturing: a U.S.-Japan comparison’, IMF Staff Papers, 36 (3), pp. 550-79.

Onaran, Ö. (2009): 'Wage share, globalization and crisis: the case of the manufacturing industry in Korea, Mexico and Turkey', International Review of Applied Economics, 23 (2), pp. 11334.

Parsley, D. C. (1993): 'Exchange rate pass-through: evidence from aggregate Japanese exports', Southern Economic Journal, 60 (2), pp. 454-62.

Pastor, R. A. (2011): The North American Idea: A Vision of a Continental Future, Oxford University Press, New York.

Revenga, A. L., Montenegro, C. E. (1998): 'North American integration and factor price equalization: is there evidence of wage convergence between Mexico and the United States?' in Collins, S. M. (ed.): Imports, Exports, and the American Worker, Brookings Institution, Washington.

Sachs, J. D., Shatz, H. (1998): 'International trade and wage inequality in the United States: some new results', in Collins, S. M. (ed.): Imports, Exports, and the American Worker, Brookings Institution, Washington.

Smith, M. A. M. (1979): 'Intertemporal gains from trade’, Journal of International Economics, 9 (2), pp. 239-48.

Steedman, I. (ed.) (1979): Fundamental Issues in Trade Theory, St. Martin’s, New York.

Steedman, I. (2005): 'The Comparative statics of industry-level produced-input-use in HOS trade theory', Review of Political Economy, 17 (3), 465-70.

Steedman, I., Metcalfe, J. S. (1979): 'Reswitching, primary inputs and the Heckscher-OhlinSamuelson theory of trade', in Steedman, I. (ed.): Fundamental Issues in Trade Theory, St. Martin's, New York.

Stolper, W., Samuelson, P. (1941): 'Protection and real wages', Review of Economic Studies, 9 (1), November, 58-73. 
Taylor, L. (1983): Structuralist Macroeconomics, Basic Books, New York.

Thompson, H. (1997): 'Free trade and income redistribution in a three factor model of the U.S. economy’, Southern Economic Journal, 63 (4), pp. 1074-83.

Woo, W. T. (1984): 'Exchange rates and the prices of nonfood, nonfuel products', Brookings Papers on Economic Activity,1984 (2), pp. 511-30. 


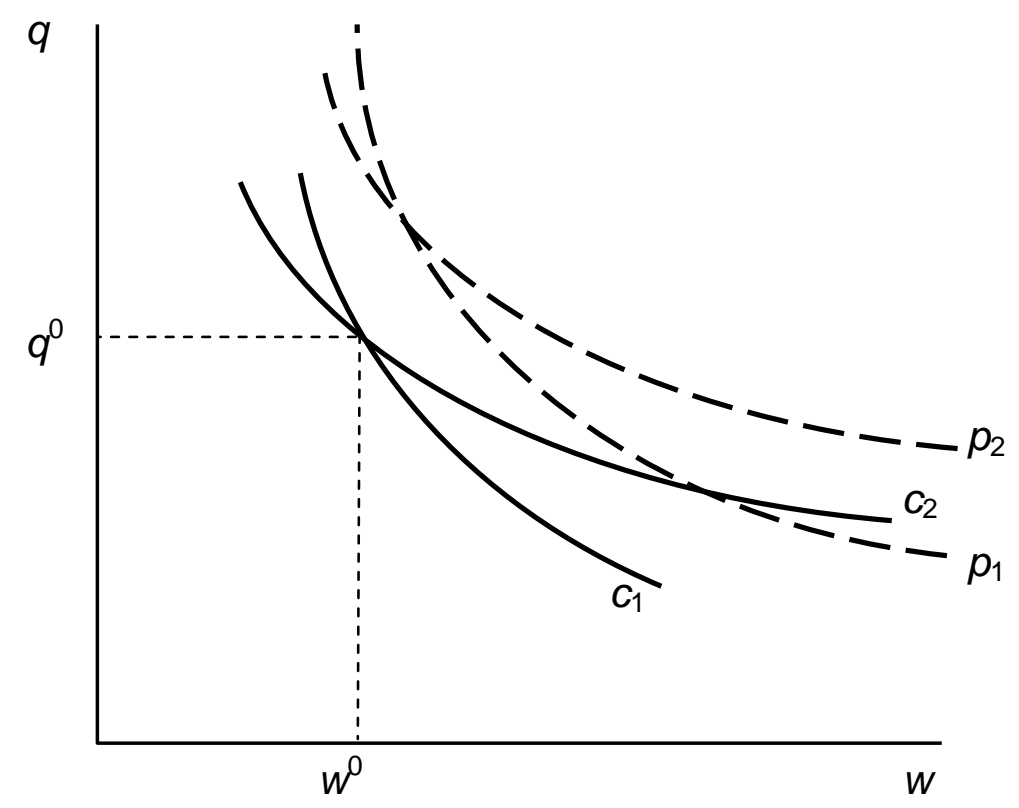

Figure 1. Relationships between factor prices ( $w$ and $q$ ), unit factor costs $\left(c_{j}\right)$, and goods prices $\left(p_{j}\right)$. 


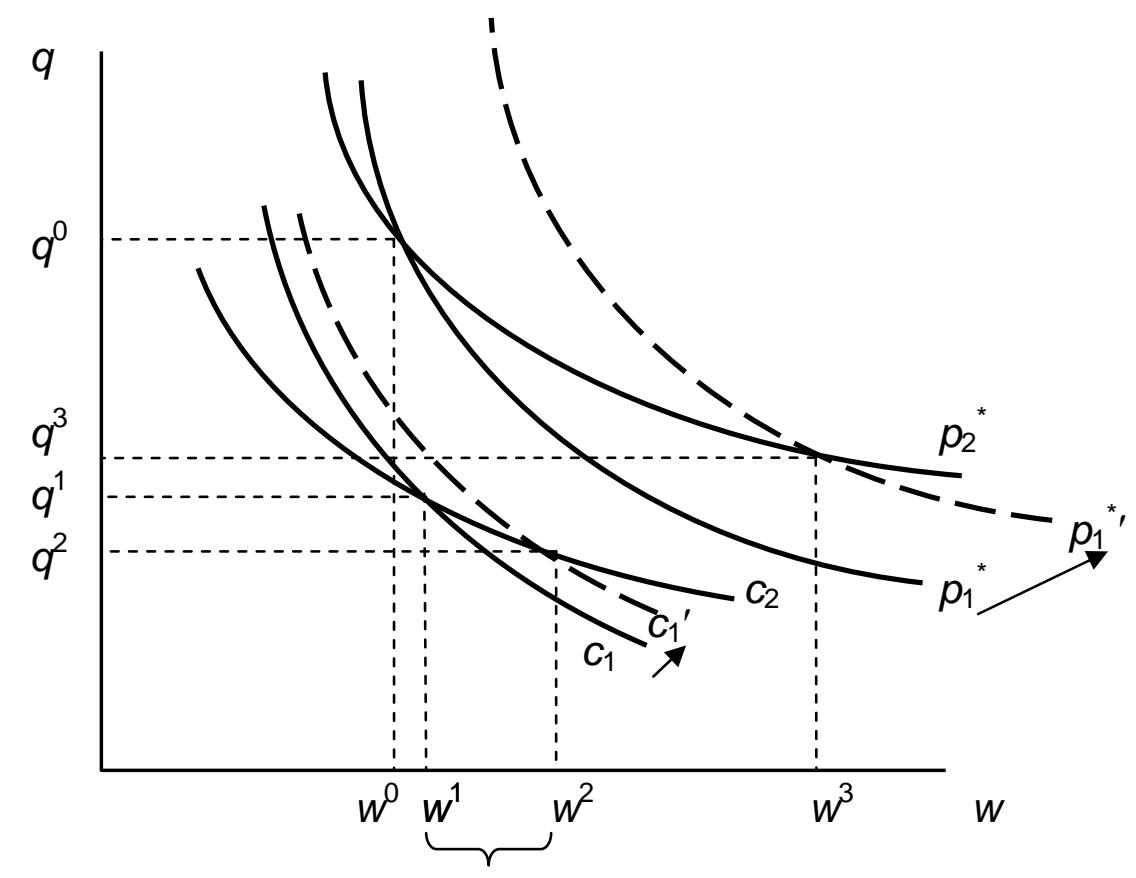

Attenuated Stolper-Samuelson effect

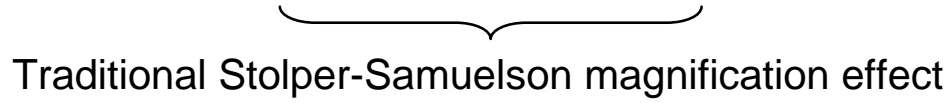

Figure 2. Effects of an increase in the foreign price of good 1 with partial pass-through into unit factor costs compared with full pass-through (variables defined as in figure 1, except $p_{j}{ }^{*}$ denotes a foreign price). 


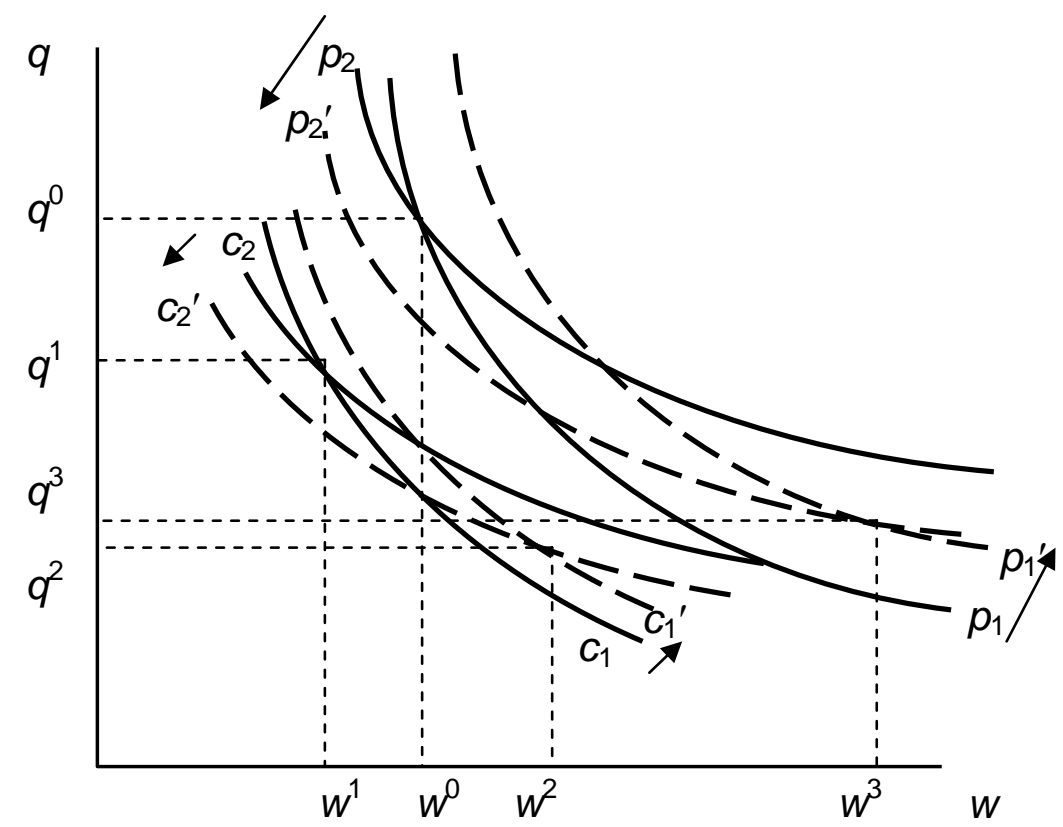

Figure 3. Effects of simultaneous trade liberalization in both industries on domestic prices of goods and factors with partial pass-through compared with full pass-through (variables defined as in figure 1). 